\title{
Comparison on cellular mechanisms of iron and cadmium accumulation in rice: prospects for cultivating Fe-rich but Cd-free rice
}

\author{
Lei Gao ${ }^{1,2}$, Jiadong Chang ${ }^{1,2}$, Ruijie Chen ${ }^{1,2}$, Hubo Li ${ }^{1,2}$, Hongfei Lu ${ }^{1,2}$, Longxing Tao ${ }^{3}$ and Jie Xiong ${ }^{1,2^{*}}$
}

\begin{abstract}
Iron (Fe) is essential for rice growth and humans consuming as their staple food but is often deficient because of insoluble Fe(III) in soil for rice growth and limited assimilation for human bodies, while cadmium (Cd) is nonessential and toxic for rice growth and humans if accumulating at high levels. Over-accumulated $\mathrm{Cd}$ can cause damage to human bodies. Selecting and breeding Fe-rich but Cd-free rice cultivars are ambitious, challenging and meaningful tasks for researchers. Although evidences show that the mechanisms of Fe/Cd uptake and accumulation in rice are common to some extent as a result of similar entry routes within rice, an increasing number of researchers have discovered distinct mechanisms between Fe/Cd uptake and accumulation in rice. This comprehensive review systematically elaborates and compares cellular mechanisms of Fe/Cd uptake and accumulation in rice, respectively. Mechanisms for maintaining Fe homeostasis and $\mathrm{Cd}$ detoxicification are also elucidated. Then, effects of different fertilizer management on Fe/Cd accumulation in rice are discussed. Finally, this review enumerates various approaches for reducing grain $\mathrm{Cd}$ accumulation and enhancing Fe content in rice. In summary, understanding of discrepant cellular mechanisms of $\mathrm{Fe} / \mathrm{Cd}$ accumulation in rice provides guidance for cultivating Fe-fortified rice and has paved the way to develop rice that are tolerant to $\mathrm{Cd}$ stress, aiming at breeding Fe-rich but Cd-free rice.
\end{abstract}

Keywords: Iron, Cadmium, Biofortification, Mugineic acid, Phytosiderophores, Phytochelatins, Harvestplus, Fertilizer management

\section{Review}

Metal elements, such as $\mathrm{Fe}, \mathrm{Zn}, \mathrm{Mn}$ and $\mathrm{Cu}$, are essential for living organisms and present as ions. Although there are abundant metal elements in the earth's crust, these ions, particularly $\mathrm{Fe}$, are sparingly soluble under aerobic conditions in high $\mathrm{pH}$ or calcareous soils and are not bioavailable to plants (Takahashi et al. 2003). As a result, Fe deficiency is a widespread agricultural problem that causes plants growth retardation and restricts sources of nutrition from plants (e.g., rice, maize and

\footnotetext{
* Correspondence: jiexiong@zju.edu.cn

${ }^{1}$ College of Life Sciences, Zhejiang Sci-Tech University, Hangzhou 310018,

People's Republic of China

${ }^{2}$ Zhejinag Province Key Laboratory of Plant Secondary Metabolism and Regulation, Hangzhou 310018, People's Republic of China

Full list of author information is available at the end of the article
}

barley) (Mori 1999; Kobayashi et al. 2010). In response to Fe deficiency, higher plants have developed two strategies for acquiring Fe from the rhizosphere (Conte and Walker, 2011; Kobayashi and Nishizawa, 2012). The application of strategy I is non-graminaceous plants, which includes the reduction of $\mathrm{Fe}(\mathrm{III})$ to soluble $\mathrm{Fe}(\mathrm{II})$ by activating membrane-bound $\mathrm{Fe}(\mathrm{III})$-chelate reductases, followed by uptake of the reduced Fe(II) into cytoplasm via $\mathrm{Fe}(\mathrm{II})$ transporters (Cheng et al. 2007). Strategy II is employed only by graminaceous plants, such as rice. Roots can secrete phytosiderophores (PSs) that belongs to the muginneic acid (MA) family to rhizosphere and chelate $\mathrm{Fe}(\mathrm{III})$, followed by uptake of $\mathrm{Fe}(\mathrm{III})$-PS complexes via specific plasma membrane transporters (Conte and Walker, 2011). Rice utilizes strategy II to acquire Fe from rhizosphere and also possesses strategy I-like 
system that can take in Fe(II) directly (Cheng et al. 2007). In spite of rice can apply specific strategies to acquire $\mathrm{Fe}$, these mechanisms have limited accessibility to resource-poor people faced with Fe deficiency from certain areas of the world. To deal with limited Fe and improve human Fe nutritional status, biofortifying rice with enhanced Fe absorption will be an effective method for populations consuming rice as their staple food.

$\mathrm{Cd}$ is a toxic heavy metal and accumulation of $\mathrm{Cd}$ in rice grains poses a latent health problem to human. $\mathrm{Cd}$ in human body can lead to chronic toxicity. The outbreak of "Itai-Itai disease" in the mid-20th century in Japan is due to consumption of Cd-contaminated rice (Uraguchi et al. 2011). A person with "Itai-Itai" has symptoms of weakness and softening of the bones (Horiguchi et al. 2010). Cd enters into environment, such as soil and river mainly through industrial activities or fertilizers (Bolan et al. 2003). As a mobile and soluble metal, $\mathrm{Cd}$ causes crops yield reduction and does harm to human health even at low concentrations (Choppala et al. 2014). The primary effects on plants caused by $\mathrm{Cd}$-induced toxic symptoms are as follows: reduced rate of transpiration and photosynthesis, growth retardation and declining metabolic activities (Choppala et al. 2014). In response to $\mathrm{Cd}$ toxicity, plants have evolved protective mechanisms against $\mathrm{Cd}$ toxicity, including "avoidance" and "tolerance" (DalCorso et al. 2010). "Avoidance", which means plants can prevent $\mathrm{Cd}$ from entering into cells and cell walls serve as the first parclose against Cd (Lang and Wernitznig, 2011; Choppala et al. 2014). Root exudates that majorly consist of sugars, proteins and organic acids are secreted from roots to soil, combining with $\mathrm{Cd}$ or keeping apart from roots (Schwab et al. 2005; Dong et al. 2007). After Cd inflows into cells, the abilities of resistance to $\mathrm{Cd}$ stress are referred to as "tolerance" (Choppala et al. 2014). A Cd chelator, phytochelatins (PC) plays a key role in Cd detoxification (Yadav et al. 2010). PC functions as chelating $\mathrm{Cd}$ in the cytosol and forming complexes with $\mathrm{Cd}$. Complexes are sequestered in the vacuoles via specific transporters located at tonoplast (Ueno et al. 2010; Miyadate et al. 2011).

There is evidence that mechanisms of $\mathrm{Fe} / \mathrm{Cd}$ uptake and accumulation in rice are common to some extent as a result of similar entry routes within rice. Nevertheless, an increasing number of researchers have discovered distinct mechanisms between $\mathrm{Fe} / \mathrm{Cd}$ uptake and accumulation. This comprehensive review systematically elaborates and compares cellular mechanisms of $\mathrm{Fe} / \mathrm{Cd}$ uptake and accumulation in rice at different stages, respectively. Mechanisms for maintaining $\mathrm{Fe}$ homeostasis and $\mathrm{Cd}$ detoxicification are elucidated. Effects of different fertilizer management on $\mathrm{Fe} / \mathrm{Cd}$ accumulation in rice are discussed. Furthermore, this review enumerates various approaches for reducing grain $\mathrm{Cd}$ accumulation and enhancing Fe content in rice. In summary, understanding of discrepant cellular mechanisms of $\mathrm{Fe} / \mathrm{Cd}$ accumulation in rice provides guidance for cultivating Fe-fortified rice and has paved the way to develop rice that are tolerant to $\mathrm{Cd}$ stress, aiming at breeding Fe-rich but $\mathrm{Cd}$-free cultivars.

\section{Primary acquisition of $\mathrm{Fe}$ and $\mathrm{Cd}$ from rhizosphere to roots of rice}

In strategy II of Fe acquisition, MAs are originated from $S$-adenosyl-1-L-methi-onine (SAM). SAM can be catalyzed by nicotianamine synthase (NAS) and produce nicotianamine (NA), which is an intermediate for the biosynthesis of MA family and a vital substance of nicotianamine aminotransferase (NAAT) (Kobayashi et al. 2010). Currently, three rice NAS genes, OsNAS1, OsNAS2 and OsNAS3 have been identified, playing different roles in Fe uptake and translocation (Inoue et al. 2003). NAAT is a critical enzyme in the biosynthesis of MAs that converts NA to 2'-deoxymugineic acid (DMA). Inoue et al. (2008) identified six rice NAAT genes (OsNAAT1-6), but only OsNAAT1 was highly upregulated under Fe deficiency, suggesting that OsNAAT1, but not OsNAAT2-6, encodes the sole functional enzyme possessing NAAT activity. DMA chelates $\mathrm{Fe}(\mathrm{III})$ and then forms $\mathrm{Fe}(\mathrm{III})$-DMA complexes, which are absorbed by root cells (Cheng et al. 2007). Cheng et al. (2007) demonstrated that NAAT1 mutant was not able to produce DMA and take up Fe(III) efficiently.

Under Fe-deficiency stress, transporters related genes for Fe uptake and translocation are transcriptionally induced (Kobayashi et al. 2014). As for rice, gene encoding DMA efflux transporters (OsTOM1) is highly expressed in response to low Fe availability (Nozoye et al. 2011). OsTOM1 encodes TOM1 transporter that localizes at plasma membrane and mediates DMA secretion to rhizosphere, followed by $\mathrm{Fe}(\mathrm{III})$-DMA complexes formation (Nozoye et al. 2011) (Fig. 1a). Yellow stripe 1 (YS1) gene that encodes $\mathrm{Fe}(\mathrm{III})$-MAs transporters was first acquired in maize. Maize YS1 mutant presents interveinal chlorosis characteristic due to Fe deficiency (Curie et al. 2001). YS1-like (OsYSL) genes in rice have been subsequently identified over the decades, among which OsYSL15 that transports Fe(III)-DMA is up-regulated in roots and shoots under Fe deficiency (Inoue et al. 2009). Fe(III)-DMA are absorbed via plasma membrane-bound OsYSL15 transporter (Inoue et al. 2009) (Fig. 1a). Furthermore, transporters that OsYSL genes encode are also involved in $\mathrm{Fe}$ translocation within rice (Koike et al. 2004; Kakei et al. 2012). Once inside the cytosol, Fe(III)DMA can be reduced by ascorbate, forming $\mathrm{Fe}(\mathrm{II})-\mathrm{NA}$ (Weber et al. 2008) (Fig. 1a). Hence, NA is not only an important intermediate for the biosynthesis of MAs, but 


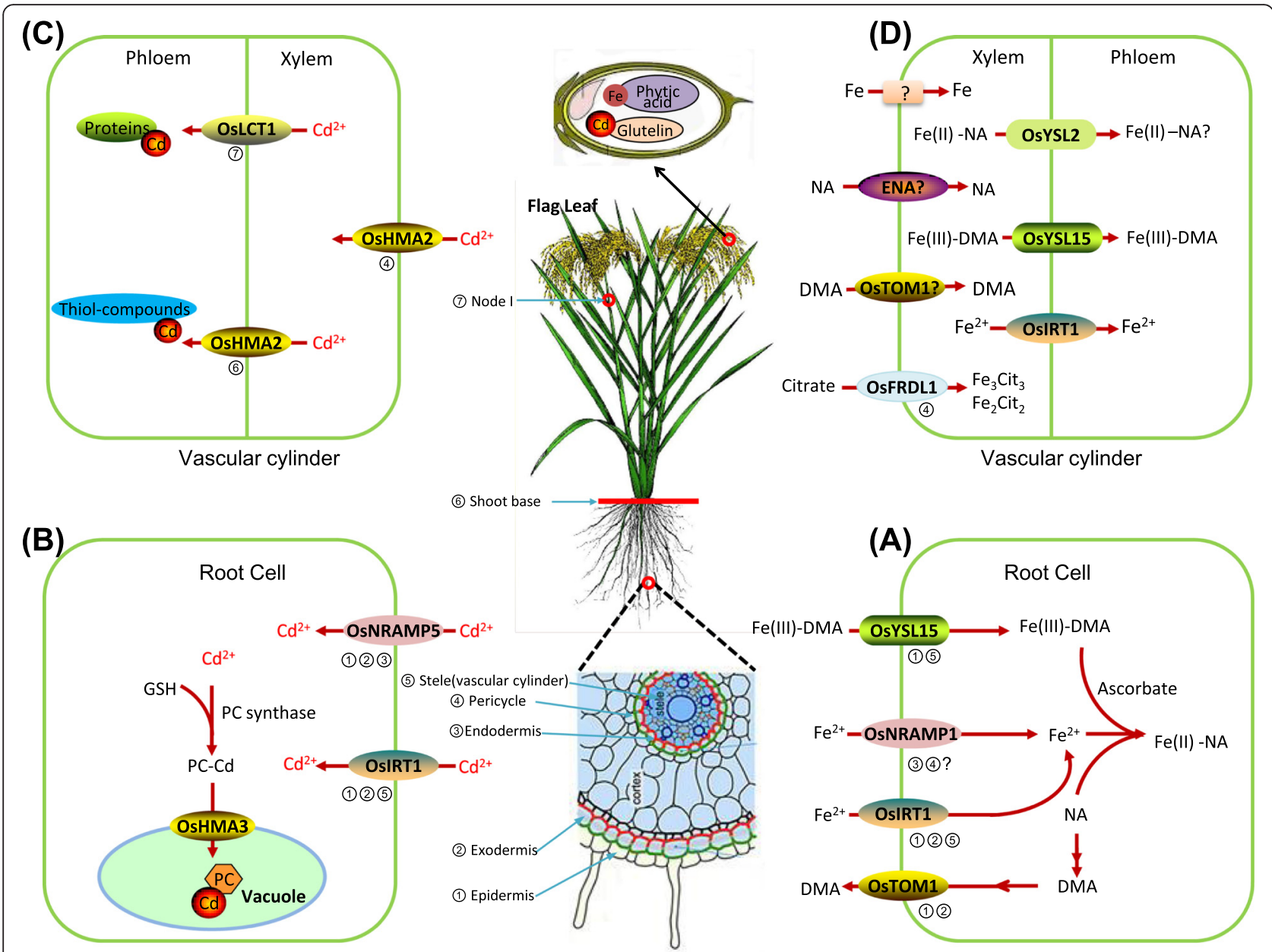

Fig. 1 Mechanisms of Fe/Cd uptake and translocation in rice. a Fe uptake from rhizosphere into root cells by specific root transporters. DMA is synthesized in cells and secreted into the rhizosphere by OsTOM1. DMA chelates rhizospheric Fe(III), forming Fe(III)-DMA complexes. Complexes are then taken up into root cells by OsYLS15. Roots also take up Fe(II) directly by metal transporters (OsIRT1/OsNRAMP1). b Cd is absorbed from rhizosphere into root cells mediated by OsIRT1 and OsNRAMP5. OsHMA3 plays a critical role in Cd compartmentalization into vacuoles in root cells. c Cd xylem loading in roots for translocation to shoots by OsHMA2, and Cd phloem loading for storage to grain sink. OsLCT1 and OsHMA2 mediate xylem-to-phloem transfer at nodes. $\mathbf{d}$ Fe xylem loading in roots for translocation to shoots and the remobilization of Fe through phloem from leaves for storage to grain sink. OsFRDL1, which is a citrate transporter localized at the root pericycle cells. OsFRDL1 loads citrate into the xylem and combines with Fe. ENA may be involved in efflux of NA into xylem. OsYSL2 then mediate Fe(II)-NA for phloem loading. OsTOM1 potentially participates in DMA transport, followed by mediating Fe(III)-DMA through OsYSL15. Furthermore, OsIRT1 directly transports Fe(II) in phloem companion cells of shoots. The encircled numerals represent the main localization of specific transporters. Right parts of the figure are adapted partially from Kobayashi et al. (2014) and Yoneyama et al. (2015)

also a significant metal chelator that can take part in translocation of Fe within plants (Takahashi et al. 2003).

In addition to $\mathrm{Fe}(\mathrm{III})$-DMA uptake, rice also absorbs $\mathrm{Fe}$ (II) via iron-regulated transporter 1 (OsIRT1) and natural resistance-associated macrophage protein 1 (OsNRAMP1) under flooded conditions (Takahashi et al. 2011) (Fig. 1a). Seven rice NRAMP genes have been identified so far (Uraguchi and Fujiwara, 2012).

The recent research indicated that plasma membranelocalized protocatechuic acid (PCA) transporter, phenolic efflux zero1/2 (PEZ1/2), also participated in $\mathrm{Fe}$ uptake (Ishimaru et al. 2011). Such transporter played a role in absorbing apoplasmic precipitated Fe by secreting phenolics like PCA or caffeic acid. Suppression of PEZ1/ 2 expression resulted in reduced $\mathrm{Fe}$ concentrations (Ishimaru et al. 2011; Kobayashi et al. 2014).

In comparison, Cd uptake from rhizosphere is a dosedependent process and exhibits saturable kinetic characteristics in rice (Fujimaki et al. 2010; Ishikawa et al. 2011). Fujimaki et al. (2010) analyzed the kinetics of $\mathrm{Cd}$ uptake by roots in rice and suggested uptake rate of $\mathrm{Cd}$ was proportional to $\mathrm{Cd}$ concentration in the culture solution within a range from 0.05 to $100 \mathrm{nM}$, demonstrating a linear relationship between uptake rate and $\mathrm{Cd}$ 
concentration in a certain range. Ishikawa et al. (2011) suggested that this kinetic characteristic of $\mathrm{Cd}$ uptake could be mediated by transporters.

$\mathrm{Cd}$ enters into root cells via transporter OsNRAMP5 or OsIRT1 and OsNRAMP5 is predominantly applied (Nakanishi et al. 2006; Sasaki et al. 2012). OsNRAMP5 expression is identified in roots epidermis, exodermis, and outer layers of the cortex as well as in tissues around the xylem (Ishimaru et al. 2012) (Fig. 1b). Knock-out of OsNRAMP5 reduces $\mathrm{Cd}$ accumulation both in straw and grains slightly (Slamet-Loedin et al. 2015). Slamet-Loedin et al. (2015) also proposed that down-regulation of $O s N$ $R A M P 5$ is a preferential strategy to decrease Cd uptake by roots. OsNRAMP5 not only mediates $\mathrm{Cd}$ uptake, but also manganese $(\mathrm{Mn})$ uptake and relatively minor effect on $\mathrm{Fe}$ uptake under Fe starvation (Ishimaru et al. 2012) (Table 1).
In addition, Takahashi et al. (2011) found that higher expression of OsNRAMP1 in roots could enhance Cd accumulation in shoots of rice, indicating that OsNRAMP1 may take part in $\mathrm{Cd}$ uptake and transport besides $\mathrm{Fe}$ absorption (Takahashi et al. 2011). Consequently, such common characteristic of transporter-mediated acquisition mechanism paves the way for $\mathrm{Cd}$ accumulation in rice.

After influx of $\mathrm{Cd}$ into cytosol, one significant pathway of $\mathrm{Cd}$ is sequestered into the vacuole via transporter OsHMA3 (Takahashi et al. 2012a) and transiently stored in the form of complexes (Choppala et al. 2014) (Fig. 1b). This pathway decreases Cd mobility in the cytosol and translocation from roots to shoots (Choppala et al. 2014; Shahid et al. 2016). OsHMA3 is mainly expressed in roots (Miyadate et al. 2011). OsHMA3 belongs to $\mathrm{P}_{1 \mathrm{~B}}$-ATPases and localizes at tonoplast (William and Mills, 2005). In

Table 1 Rice genes involved in Fe/Cd transport and induced status under Fe deficiency and Cd stress

\begin{tabular}{|c|c|c|c|c|}
\hline Gene name & RAP ID & Function & $\begin{array}{l}\text { Induced status under Fe } \\
\text { deficiency and Cd stress }\end{array}$ & References \\
\hline \multicolumn{5}{|c|}{ NA/DMA biosynthesis for Fe(III)-DMA or Fe(II)-NA transport } \\
\hline OsNAS1 & Os03g0307300 & Nicotianamine synthase & $\uparrow$ & Cheng et al. 2007 \\
\hline OsNAS2 & Os03g0307200 & Nicotianamine synthase & $\uparrow$ & Cheng et al. 2007 \\
\hline OsNAS3 & Os07g0689600 & Nicotianamine synthase & $\uparrow($ root $) \downarrow($ leaf $)$ & Cheng et al. 2007 \\
\hline OsNAAT1 & Os02g0306401 & Nicotianamine aminotransferase & $\uparrow$ & Inoue et al. 2008 \\
\hline OsDMAS1 & Os03g0237100 & Deoxymugineic acid & $\uparrow$ & Kobayashi et al. 2014 \\
\hline \multicolumn{5}{|c|}{ Transporters for Fe/Cd uptake and translocation } \\
\hline OSTOM1 & Os11g0134900 & DMA efflux transporter & $\uparrow$ & Nozoye et al. 2011 \\
\hline OsYSL15 & Os02g0650300 & Fe(III)-DMA transporter & $\uparrow$ & Inoue et al. 2009 \\
\hline OsYSL16 & Os04g0542800 & Fe(III)-DMA transporter & $\rightarrow$ & Kakei et al. 2012 \\
\hline PEZ1 & Os03g0571900 & Phenolics efflux transporter & - & Ishimaru et al. 2011 \\
\hline PEZ2 & Os03g0572900 & Phenolics efflux transporter & - & Ishimaru et al. 2012 \\
\hline OsIRT1 & Os03g0667500 & Ferrous Fe transporter & $\uparrow$ & Takahashi et al. 2011 \\
\hline OSIRT2 & Os03g0667300 & Ferrous Fe transporter & $\uparrow$ & Takahashi et al. 2011 \\
\hline OsNRAMP1 & Os07g0258400 & Ferrous Fe/Cd transporter & $\uparrow$ & Takahashi et al. 2011 \\
\hline OsNRAMP5 & Os07g0257200 & Ferrous $\mathrm{Fe} / \mathrm{Cd} / \mathrm{Mn}$ transporter & $\uparrow$ & Ishimaru et al. 2011 \\
\hline OSFRDLI & Os03g0216700 & Citrate efflux transporter & $\rightarrow$ & Kobayashi et al. 2014 \\
\hline ENA1 & Os11g0151500 & NA efflux transporter & $\uparrow($ root $) \downarrow($ shoot $)$ & Nozoye et al. 2011 \\
\hline ENA2 & Os06g0695800 & NA efflux transporter & $\uparrow($ root $) \downarrow$ (shoot) & Nozoye et al. 2011 \\
\hline OSYSL2 & Os02g0649900 & Ferrous Fe/Mn-NA transporter & $\uparrow$ & Ishimaru et al. 2010 \\
\hline OsHMA2 & Os06g0700700 & $\mathrm{Cd} / \mathrm{Zn}$ transporter & $\uparrow$ & Yoneyama et al. 2015 \\
\hline OsLCT1 & Os06g0579200 & Cd efflux transporter & - & Uraguchi et al. 2011 \\
\hline \multicolumn{5}{|c|}{ Transporters for cellular Fe/Cd sequestration } \\
\hline OsVIT1 & Os04g0463400 & Fe import into vacuole & $\rightarrow$ & $\begin{array}{l}\text { Pich et al. 2001; } \\
\text { Zhang et al. } 2012\end{array}$ \\
\hline OsVIT2 & Os09g0396900 & Fe import into vacuole & $\downarrow$ & $\begin{array}{l}\text { Pich et al. 2001; } \\
\text { Zhang et al. } 2012\end{array}$ \\
\hline OsHMA3 & Os07g0232900 & Cd import into vacuole & - & Takahashi et al. 2012a \\
\hline OsABCG43 & Os07g0522500 & Cd import into vacuole & - & Oda et al. 2011 \\
\hline
\end{tabular}

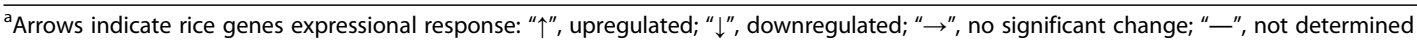


Arabidopsis thaliana, AtHMA3, similar as OsHMA3, is responsible for sequestration of $\mathrm{Cd}$ into vacuoles (Miyadate et al. 2011). Meanwhile, an allele of OsHMA3 was discovered to fail to transport $\mathrm{Cd}$ into vacuole in $\mathrm{Cd}$ high-accumulating cultivars such as some indica cultivars. Owing to non-function of OsHMA3, Cd is accelerated to distribute within rice, leading to high accumulation. These cultivars presented high $\mathrm{Cd}$ accumulation in the shoots and grains (Miyadate et al. 2011).

\section{Translocation of $\mathrm{Fe}$ and $\mathrm{Cd}$ from roots to shoots}

Following uptake by roots, $\mathrm{Fe}$ and $\mathrm{Cd}$ are transported to shoots via xylem and phloem, where exist a large amount of vascular bundles (Yoneyama et al. 2015). This radial transport system includes symplasmic and apoplasmic pathways, but the former pathway is predominantly utilized as a result of impediment by Casparian strips occuring in apoplasmic pathway (Enstone et al. 2002). After $\mathrm{Fe}(\mathrm{II})-\mathrm{NA}$ formation in the cytosol, $\mathrm{Fe}(\mathrm{II})$ $\mathrm{NA}$ is transported to xylem and exchanges NA with citrate, transforming to $\mathrm{Fe}(\mathrm{III})$-citrate preferentially (Yokosho et al. 2009; Ariga et al. 2014). Fe in the xylem is largely in the form of Fe-citrate and then allocated to all leaves, whereas $\mathrm{Fe}$ in the phloem is mainly bound to DMA, citrate and proteins (Yoneyama et al. 2015). The translocation of citrate from root pericycle cells to xylem is mediated by ferric reductase defective1-like transporter (OsFRDL1) (Yokosho et al. 2009) (Fig. 1d). OsFRDL1 is constitutively expressed in root pericycle cells and transporter OsFRDL1 is specifically required for Fe translocation (Yokosho et al. 2009).

Phloem loading is the upcoming step. Transporter OsYSL2 plays a part in Fe distribution in the phloem, localizing at the plasma membrane and is responsible for $\mathrm{Fe}(\mathrm{II})-\mathrm{NA}$ or $\mathrm{Mn}(\mathrm{II})-\mathrm{NA}$ transport, but not for $\mathrm{Fe}(\mathrm{III})$ DMA transport (Ishimaru et al. 2010) (Table 1). OsYSL2 knock-down rice lines accumulated less $\mathrm{Fe}$ and $\mathrm{Mn}$ in shoots and seeds (Kobayashi et al. 2010). With regard to mechanism for efflux of NA into xylem in specific way, Nozoye et al. (2011) proposed that the NA efflux transporters (ENA1/2) are responsible for the effux of NA into xylem or intracellular compartments in order to redistribute Fe (Fig. 1d). Under Fe deficiency, both OsYSL2 and ENA1 are strongly induced (Ishimaru et al. 2010; Ogo et al. 2014). In addition to transporter OsYSL2, OsYSL15 is considered to transport Fe(III)-DMA for phloem trafficking and expressed in the phloem companion cells (kobayashi et al. 2010; kakei et al. 2012; Kobayashi et al. 2014) (Fig. 1d). Thereafter, Fe is delivered to grain via phloem in forms of Fe(III)-DMA or binds to some citrate and proteins (Yoneyama et al. 2015).

As for Cd translocation, once $\mathrm{Cd}$ enters into root cells, part of $\mathrm{Cd}$ present as Cd-phytochelatin (Cd-PC) complexes are sequestered in the vacuoles and the others are transported to xylem mediated by OsHMA2 transporter. Such xylem loading occurs in root pericycle cells with OsHMA2 (Takahashi et al. 2012b; Yamagi et al. 2013; Yoneyama et al. 2015) (Fig. 1c). Moreover, OsHMA2 is also involved in xylem-to-phloem transfer (Yoneyama et al. 2015). In the phloem, Cd primarily bounds to specific proteins and slightly to thiol-compouds (White and Broadley 2011). In contrast to Fe translocation that is mainly derived from leaves by remobilization, xylem-tophloem transfer system of $\mathrm{Cd}$ mainly occurs at the nodes (Fujimaki et al. 2010). In rice nodes, the diffuse vascular bundles (DVBs) that encircle the enlarged elliptical vascular bundles (EVBs) are connected to the panicle (Yamaguchi et al. 2012). A study demonstrated that $\mathrm{Cd}$ was predominantly transported towards the panicle instead of other tissues at the panicle-initiation stage through the nodes and ultimately reached grain by prositron-emitting ${ }^{107} \mathrm{Cd}$ tracer imaging system (PETIS) (Fujimaki et al. 2010). Node I, the uppermost node, is connected to both flag leaf and panicle. The large vascular bundles (LVBs) of flag leaf are linked to the EVBs. Metals, such as $\mathrm{Cd}$, that are not transported to the panicle can be shifted to flag leaf (Uraguchi et al. 2011). Yamaguchi et al. (2012) found that Cd concentration was higher in the node I than in blade, culm and panicle due to the accumulation of $\mathrm{Cd}$. Furthermore, A lowaffinity cation transporter (OsLCT1), which is highly expressed in the node I, participates in $\mathrm{Cd}$ transport to grain (Uraguchi et al. 2011) (Fig. 1c). OsLCT1 is identified as a plasma membrane-localized transporter by subcellular localization of OsLCT1-sGFP (Uraguchi et al. 2011). Suppression of OsLCT1 exppression can efficiently decrease grain Cd levels (Uraguchi et al. 2011).

Therefore, Node is deemed to be an important "transportation junction" responsible for $\mathrm{Cd}$ distribution. Shoot base contains the lower packed nodes with numerous vascular bundles, designated as the "traffic control centre", and where $\mathrm{Cd}$ can be separated into the tillers, accumulating in each node (Fujimaki et al. 2010).

\section{Role of cellular sequestration in mitigating $\mathrm{Cd}$ toxicity}

As stated in the introduction section above, Plants have developed numerous resistance mechanisms against $\mathrm{Cd}$ toxicity, "avoidance" and "tolerance" included. "Avoidance" is first employed and serves as a basic mechanism to relieve $\mathrm{Cd}$ toxicity. However, "tolerance", which makes plants survive in the presence of $\mathrm{Cd}$ stress, plays a major role in mitigating $\mathrm{Cd}$ toxicity. In the "tolerance" mechanisms, deposition of $\mathrm{Cd}$ in the cell wall is a first barrier to restrict $\mathrm{Cd}$ movement by combining with composition of cell wall (Carrier et al. 2003; Choppala et al. 2014) (Table 2). Xiong et al. (2009) first proved that exogenous NO could be involved in regulation of root cell wall composition to alleviate $\mathrm{Cd}$ toxicity. Enhanced 
Table 2 Comparison on mechanisms of $\mathrm{Fe} / \mathrm{Cd}$ detoxicfication in rice

\begin{tabular}{|c|c|c|c|}
\hline Mechanisms & $\mathrm{Fe}$ & $\mathrm{Cd}$ & References \\
\hline \multicolumn{4}{|l|}{ Cellular sequestration } \\
\hline Storage sites & $\begin{array}{l}\text { Vacuole in the flag leaves and } \\
\text { sheaths }\end{array}$ & Vacuole in the root cells and leaves & $\begin{array}{l}\text { Choppala et al. 2014; } \\
\text { Pich et al. 2001; }\end{array}$ \\
\hline Chemical forms & $\mathrm{Fe}(I I)-\mathrm{NA}$ & $\mathrm{Cd}-\mathrm{PC}$ & Takahashi et al. 2012a; \\
\hline Mediated transporters & OsVIT1/2 & OsHMA3 & Zhang et al. 2012 \\
\hline Location of transporters & Tonoplast & Tonoplast & \\
\hline \multicolumn{4}{|c|}{ Combination of $\mathrm{Fe} / \mathrm{Cd}$ and organics } \\
\hline Storage sites & $\begin{array}{l}\text { Chloroplast or embryo in the } \\
\text { leaves and seeds }\end{array}$ & Cell wall in the roots and leaves & $\begin{array}{l}\text { Ravet et al. 2009; } \\
\text { Xiong et al. } 2009\end{array}$ \\
\hline Chemical forms & Fe-Ferritin & Cd-Pectin and Cd-Hemicellulose & \\
\hline
\end{tabular}

pectin and hemicellulose contents (Table 2) induced by exogenous $\mathrm{NO}$ in root cell wall increased $\mathrm{Cd}$ deposition in cell wall and decreased $\mathrm{Cd}$ distribution within rice. Once entering into cell, PC that acts as a chelator can make complexes with $\mathrm{Cd}$, forming Cd-PC (Table 2). Basic structure of $\mathrm{PC}$, consisting of glutamate, cysteine and glycine has been identified (Rauser 1995), and glutathione (GSH) is a key intermediate for the biosynthesis of PC and catalyzed by PC synthase (PCS) (Rauser 1995; Cobbett 2000). PCS can be activated in the presence of Cd (Cobbett 2000). As for rice, in the root cells, Cd-PC complexes are stored in the vacuoles mediated by tonoplast-localized transporter OsHMA3 (Tables 1 and 2), followed by dissociation in the vacuoles due to acidic environment (Johanning and Strasdeit 1998; Takahashi et al. 2012a, b; Choppala et al. 2014). Dissociated PC can be recycled in the next round (Johanning and Strasdeit 1998).

According to this cellular mechanism, subsequent movement of $\mathrm{Cd}$ through the root symplasm to the xylem can be limited (Nocito et al. 2011). Some reports pointed that OsHMA3 is expressed in shoots besides roots, which implies the key factor of OsHMA3 in determining rootto-shoot transfer of $\mathrm{Cd}$ and regulation of $\mathrm{Cd}$ distribution within rice. Particularly, cellular sequestration mediated by OsHMA3 in root cells is a rate-limiting step (Ueno et al. 2010). Furthermore, an ABC-type transporter OsABCG43 is also considered to be a probable candidate for $\mathrm{Cd}$ tolerance in rice (Oda et al. 2011; Uraguchi and Fujiwara 2012). OsABCG43 is likely to sequester $\mathrm{Cd}$ at the subcellular level, as well as vacuolar sequestration mediated by OsHMA3 (Oda et al. 2011) (Table 1). Nevertheless, whether there are other mechanisms mediated by OsABCG43 is far from clear.

\section{Mechanisms for maintaining Fe homeostasis}

Despite enhancing Fe is primary concern to agricultural production, over-accumulated Fe can cause cellular damage since Fe is highly reactive (Conte and Walker, 2011). $\mathrm{Fe}(\mathrm{II})$ is considered to be a source of reactive oxygen species (ROS), which results in oxidative damage (Curie et al. 2009). Thus, maintaining Fe homeostasis is crucial to plant growth. Plant has evolved Fe homeostatic mechanisms that regulate $\mathrm{Fe}$ acquisition. Once taken up into cells, Fe is subjected to strict control to avoid cellular damage. Ferritin, a Fe storage protein, can combine with Fe atoms in bioavailable and non-toxic form for distribution within plants and protect against Fe-mediated oxidative stress (Liu et al. 2003; Ravet et al. 2009) (Table 2). Besides ferritin, nitric oxide (NO) is a promising candidate for serving as a scavenger of ROS, and the reduction of nitrite by nitrite reductase (NR) is a major pathway to generate NO (Crawford 2006). Moreover, vacuolar sequestration is another significant mechanism in controlling Fe homeostasis. Vacuole functions as buffering pool in conditions of $\mathrm{Fe}$ toxicity through the interaction between tonoplast-localized transporters and Fe chelators (Table 2). As mentioned from the above, NA is also involved in intracellular movements and acts as a strong chelator of Fe (Table 2). Excess Fe, as well as $\mathrm{Cd}$ compartmentalization, can be chelated by NA and sequestrated in the vacuole (Pich et al. 2001). In rice, OsVIT1 and OsVIT2 that encode vacuolar transporters are highly expressed in flag leaf and sheath, respectively, transporting excess Fe into vacuole (Zhang et al. 2012) (Tables 1 and 2).

\section{Effects of fertilizers on $\mathrm{Fe}$ and $\mathrm{Cd}$ accumulation discrepancy in rice}

Enhancing $\mathrm{Fe}$ concentration in grains through waterfertilizer management is a kind of agronomic biofortification though the strategy plays a role in a short term (Slamet-Loedin et al. 2015). Nitrogen (N) is an essential macronutrient for plants (Sarwar et al. 2010). N application promotes YSL protein synthesis and nitrogenous compounds formation, such as NA and DMA, both of which participate in Fe transport in rice (Slamet-Loedin et al. 2015) (Table 3). Moreover, increased N application results in more biomass production and reduces Cd toxicity to some extent due to dilution effect 
Table 3 Positive and negative effects caused by fertilizer types on Fe/Cd accumulation in rice

\begin{tabular}{|c|c|c|c|}
\hline Fertilizer types & Positive effects & Negative effects & References \\
\hline \multirow[t]{4}{*}{ Nitrogen $\left(\mathrm{NH}^{4+} / \mathrm{NO}^{3-}\right)$} & $\begin{array}{l}\text { Increased YSL protein synthesis and nitrogenous } \\
\text { compounds formation for Fe transport }\end{array}$ & $\begin{array}{l}\text { Decreased soil } \mathrm{pH} \text { and membrane } \\
\text { depolarization by } \mathrm{NH}^{4+} \text { application }\end{array}$ & \multirow{4}{*}{$\begin{array}{l}\text { Zaccheo et al. 2006; } \\
\text { Wangstrand et al. 2007; } \\
\text { Xie et al. 2009; } \\
\text { Sarwar et al. 2010; } \\
\text { Slamet-Loedin et al. 2015; } \\
\text { Yang et al. 2016b }\end{array}$} \\
\hline & $\begin{array}{l}\text { Increased soluble protein content reduce } \\
\text { mobility of Cd }\end{array}$ & \multirow[t]{3}{*}{$\begin{array}{l}\text { Up-regulated expression of } \mathrm{Fe} / \mathrm{Cd} \\
\text { co-transporters by excess } \mathrm{NO}^{3-} \\
\text { application }\end{array}$} & \\
\hline & $\begin{array}{l}\text { Higher antioxidase activity by } \mathrm{NH}^{4+} \text { application } \\
\text { reduce Cd toxicity }\end{array}$ & & \\
\hline & $\begin{array}{l}\text { High soil } \mathrm{pH} \text { and membrane polarization by } \\
\mathrm{NO}^{3-} \text { application produce } \mathrm{Cd} \text { detoxcification }\end{array}$ & & \\
\hline \multirow[t]{3}{*}{ Phosphorus } & Insoluble Cd formation in soil & Limited source of $P$ fertilizer & \multirow{3}{*}{$\begin{array}{l}\text { Cordell et al. 2009; } \\
\text { Wang et al. 2009; } \\
\text { Sarwar et al. } 2010\end{array}$} \\
\hline & GSH biosynthesis participation & $\begin{array}{l}\text { Decreased soil pH enhance solubility } \\
\text { of } \mathrm{Cd}\end{array}$ & \\
\hline & Increased antioxidase activity by $P$ application & & \\
\hline \multirow[t]{3}{*}{ Iron } & $\begin{array}{l}\text { Compete with } \mathrm{Cd} \text { for the same binding site } \\
\text { under anaerobic conditions }\end{array}$ & $\begin{array}{l}\text { Increased } \mathrm{Cd} \text { concentration by some } \\
\mathrm{Fe}^{2+} \text { fertilizers }\left(\text { e.g. } \mathrm{FeSO}_{4} \text { ) application }\right.\end{array}$ & \multirow{3}{*}{$\begin{array}{l}\text { Sharma et al. 2004; } \\
\text { Shao et al. 2008; } \\
\text { Liu et al. 2008; } \\
\text { Rizwan et al. } 2016\end{array}$} \\
\hline & Alleviate oxidative stress caused by $\mathrm{Cd}$ & & \\
\hline & Iron plague formation & & \\
\hline \multirow[t]{2}{*}{ Zinc } & Compete with $\mathrm{Cd}$ for the same transporters & $\begin{array}{l}\text { Simultaneous } \mathrm{Zn} / \mathrm{Cd} \text { absorption by } \\
\text { root cells }\end{array}$ & \multirow{2}{*}{$\begin{array}{l}\text { Smilde et al. 1992; } \\
\text { Aravind et al. 2009; } \\
\text { Sarwar et al. 2010; } \\
\text { Fahad et al. 2015; } \\
\text { Rizwan et al. 2016 }\end{array}$} \\
\hline & Alleviate oxidative stress caused by $\mathrm{Cd}$ & $\begin{array}{l}\text { Enhanced } \mathrm{Cd} \text { concentration caused } \\
\text { by high level of } \mathrm{Zn}\end{array}$ & \\
\hline \multirow[t]{4}{*}{ Silicon } & Increased soil pH reduce mobility of $\mathrm{Cd}$ & & \multirow{4}{*}{$\begin{array}{l}\text { Sarwar et al. 2010; } \\
\text { Wang et al. 2015; } \\
\text { Rizwan et al. } 2016\end{array}$} \\
\hline & Si-Cd complexes formation & & \\
\hline & Enhanced antioxidase activity & & \\
\hline & Enhanced Fe level & & \\
\hline \multirow[t]{3}{*}{ Sulfur } & Insoluble $\mathrm{CdS}$ formation reduce mobility of $\mathrm{Cd}$ & $\begin{array}{l}\text { Increased soil pH enhance } \mathrm{Cd} \\
\text { concentration and mobility }\end{array}$ & \multirow[t]{3}{*}{$\begin{array}{l}\text { Hassan et al. 2005; } \\
\text { Rehman et al. } 2015\end{array}$} \\
\hline & GSH biosynthesis participation & & \\
\hline & Iron plague formation & & \\
\hline
\end{tabular}

(Sarwar et al. 2010). Such effect is mainly caused by increased soluble protein content in crops that can transform mobile $\mathrm{Cd}$ to immobile form by binding (Sarwar et al. 2010) (Table 3). Different N fertilizer forms also have relationships with $\mathrm{Fe} / \mathrm{Cd}$ uptake and accumulation in both roots and shoots (Mitchell et al. 2000). Ammonium $\left(\mathrm{NH}_{4}^{+}\right)$and nitrate $\left(\mathrm{NO}_{3}^{-}\right)$are primary $\mathrm{N}$ fertilizer forms for rice absorption and assimilation (Jalloh et al. 2009). In the paddy soil, $\mathrm{NH}_{4}^{+}$containing fertilizer is predominantly employed (Araki et al. 2015). Higher antioxidase activity exposure to $\mathrm{NH}_{4}^{+}$treatment is considered as protective mechanism against Cd stress (Rizwan et al. 2016) (Table 3). Although the preferential application of $\mathrm{NH}_{4}^{+}$over $\mathrm{NO}_{3}^{-}$ as a nitrogen source for rice, many reports proved that combination of $\mathrm{NH}_{4}^{+}$and $\mathrm{NO}_{3}^{-}$is better for rice growth (Sarwar et al. 2010; Araki et al. 2015).

$\mathrm{Cd}$ in acidic soil is ionized as $\mathrm{Cd}^{+}$(Khaokaew et al. 2011), which can promote mobilization of Cd (Sarwar et al. 2010). Rhizosphere acidification caused by $\mathrm{NH}_{4}^{+}$-containing fertilizer derives from proton excretion by root cells, exchanging with $\mathrm{NH}_{4}^{+}$and leading to low $\mathrm{pH}$ in soil (Zaccheo et al. 2006). In low pH soil, $\mathrm{Cd}$ is mobile to move towards root system and translocates within plants, resulting in $\mathrm{Cd}$ accumulation (Table 3). In addition, $\mathrm{NH}_{4}^{+}$can trigger cell membrane depolarization and lead to influx of $\mathrm{NH}_{4}^{+}$into root cells, which accelerates translocation of $\mathrm{Cd}$ from root to shoot though this mechanisms reduces $\mathrm{Cd}$ uptake in a certain way (Zaccheo et al. 2006; Sarwar et al. 2010) (Table 3). Consequently, $\mathrm{NH}_{4}^{+}$-containing fertilizer is considered to contribute to enhance $\mathrm{Cd}$ uptake (Sarwar et al. 2010). Compared with $\mathrm{NH}_{4}^{+}$-containingfertilizer, $\mathrm{NO}_{3}^{-}$containing fertilizer causes simultaneous $\mathrm{NO}_{3}^{-}$and proton absorption by root cells, leading to high $\mathrm{pH}$ (Eriksson, 1990) and cell membrane polarization caused by nitrate can produce $\mathrm{Cd}$ detoxification mechanism (Sarwar et al. 2010) (Table 3). Nevertheless, Xie et al. (2009) found that plants supplied with $\mathrm{NO}_{3}^{-}$accumulated more $\mathrm{Cd}$ than $\mathrm{NH}_{4}^{+}$treatment by Thlaspi caerulesscens in hydroponic experiment, suggesting that effects of $\mathrm{NH}_{4}^{+}$and $\mathrm{NO}_{3}^{-}$on $\mathrm{Cd}$ uptake are not simply attributed to rhizosphere $\mathrm{pH}$ 
transformation or charge distribution of cell membrane. Yang et al. (2016b) found that rice fed with excess $\mathrm{NO}_{3}^{-}$ not only enhanced Fe uptake, but also increased Cd uptake by up-regulating the expression of OsIRT1. It deserves further study that $\mathrm{N}$ fertilizer might enhance $\mathrm{Cd}$ uptake and accumulation resulting from up-regulated expression of common $\mathrm{Cd} / \mathrm{Fe}$ transporter genes (Table 3). Wangstrand et al. (2007) once proposed that application of $\mathrm{N}$ fertilizer is dependent on different growth stages and recommended that more $\mathrm{N}$ fertilizer should be applied at the vegetative stage while less $\mathrm{N}$ doses should be applied during the grain filling stage. Therefore, the application of $\mathrm{N}$ fertilizer on rice can be manipulated to decrease $\mathrm{Cd}$ content and enhance Fe content. Meanwhile, selection of proper $\mathrm{N}$ fertilizer forms according to different growth stages is still hot research field.

Besides application of $\mathrm{N}$ fertilizer, other mineral fertilizers also contribute to rice growth as well. Phosphorus $(\mathrm{P})$ is another important plant nutrient and applied to plant as fertilizer. In contrast to N, P is a non-renewable natural resource and there is growing concern about limited source of P fertilizer (Cordell et al. 2009). Most of $\mathrm{P}$ are derived from rock phosphate containing $\mathrm{Cd}$ and hence result in Cd contamination in soil (Lambert et al. 2007; Sarwar et al. 2010). Sarwar et al. (2010) mentioned that mono-ammonium-phosphate (MAP) could enhance $\mathrm{Cd}$ uptake due to increased solubility of $\mathrm{Cd}$ by lowering soil $\mathrm{pH}$ (Table 3). However, $\mathrm{P}$ fertilizer also reduce solubility of $\mathrm{Cd}$ by insoluble $\mathrm{Cd}$ formation, such as $\mathrm{Cd}(\mathrm{OH})_{2}$ or $\mathrm{Cd}_{3}\left(\mathrm{PO}_{4}\right)_{2}$ (Bolan et al. 2003) (Table 3). Furthermore, crops have developed intrinsic mechanisms against $\mathrm{Cd}$ stress caused by rock phosphate containing Cd (Sarwar et al. 2010; Slamet-Loedin et al. 2015). Slamet-Loedin et al. (2015) mentioned that minor effect of P fertilizerrelated $\mathrm{Cd}$ uptake on rice. $\mathrm{P}$ is involved in glutathione (GSH) biosynthesis (Table 3), which is precursor of PC. Recently, Yang et al. (2016a) proposed that P deprivation decreases $\mathrm{Cd}$ uptake by inhibiting biomass accumulation and reducing PCs synthesis. As elucidated above, in rice, $\mathrm{PC}$ can form complexes with $\mathrm{Cd}$ after $\mathrm{Cd}$ is transported into vacuole, alleviating $\mathrm{Cd}$ toxicity efficiently (May et al. 1998; Sarwar et al. 2010). On the other hand, an increase in antioxidase activity by the application of $\mathrm{P}$ plays an indispensable role in alleviating oxidative stress caused by Cd toxicity (Wang et al. 2009) (Table 3). In summary, as well as $\mathrm{N}$ application, appropriate $\mathrm{P}$ application is necessary for rice growth.

Application of $\mathrm{Fe}$ fertilizer is direct and effective method for enhancing $\mathrm{Fe}$ content while reducing $\mathrm{Cd}$ toxicity to some extent. Under anaerobic conditions, such as flooded status, $\mathrm{Fe}^{2+}$ is dominant chemical form in soil (Sarwar et al. 2010). Owing to similar chemical form, $\mathrm{Fe}^{2+}$ compete with $\mathrm{Cd}$ for the same binding site and transport systems on the surface of root cells (Table 3), reducing $\mathrm{Cd}$ uptake in a certain way accordingly (Sarwar et al. 2010). Nevertheless, different types of $\mathrm{Fe}^{2+}$ fertilizer may have discrepant effects on $\mathrm{Cd}$ accumulation. Shao et al. (2008) showed that application of $\mathrm{FeSO}_{4}$ remarkably increased $\mathrm{Cd}$ concentrations in roots and shoots of rice (Table 3). Thus, selection of appropriate Fe type is conducive to rice growth. Furthermore, Fe is important co-factor of antioxidase, which can provide protective mechanisms against oxidative stress (Sharma et al. 2004) (Table 3). A peculiar mechanism against $\mathrm{Cd}$ stress by application of Fe fertilizer is iron plague (IP) formation (Rizwan et al. 2016) (Table 3). This IP can serve as a barrier and prevent $\mathrm{Cd}$ from entering into root cells, resulting in reduced $\mathrm{Cd}$ accumulation while enhanced Fe concentration in rice (Liu et al. 2008).

Zinc is an essential micronutrient for crops growth. As a result of similar physical and chemical characteristics (Rizwan et al. 2016), the interactions between $\mathrm{Zn}$ and Cd, synergistic and antagonistic effect (Fahad et al. 2015; Rizwan et al. 2016), have been an issue to be solved for the field of agricultural science. In antagonistic way, $\mathrm{Zn}$ will compete with $\mathrm{Cd}$ for the same membrane transporters (Table 3), restricting Cd uptake by root cells. In synergistic way, both of $\mathrm{Zn}$ and $\mathrm{Cd}$ are absorbed by root cells, increasing $\mathrm{Cd}$ accumulation in rice (Sarwar et al. 2010) (Table 3). Xue and Harrison (1991) discovered that higher level of $\mathrm{Zn}$ fertilizer application causes enhanced $\mathrm{Cd}$ concentration in lettuce leaves. Smilde et al. (1992) also identified that increased Zn concentration in soil leaded to high $\mathrm{Cd}$ concentration in leafy vegetables (Table 3). Hence, controlling Zn fertilizer application at an optimum level may reduce $\mathrm{Cd}$ concentration caused by synergistic effect. In addition, $\mathrm{Zn}$ application is involved in alleviating oxidative stress (Table 3) caused by $\mathrm{Cd}$ and has protective mechanisms against reactive oxygen species (ROS) that result in cell membrane damage (Aravind et al. 2009).

Silicon ( $\mathrm{Si}$ ) is thought to be an enhancer for crops growth though it is not an essential element (Rizwan et al. 2016). Wang et al. (2015) found that Si application could enhance Fe level in rice (Table 3). Si application can reduce mobility of $\mathrm{Cd}$ due to increased $\mathrm{pH}$ in soil (Sarwar et al. 2010) (Table 3). Complexes formation of Si with $\mathrm{Cd}$ is another mechanism for alleviating $\mathrm{Cd}$ toxicity in rice (Rizwan et al. 2016) (Table 3). Moreover, Si application can also enhance antioxidase activity (Sarwar et al. 2010) (Table 3).

Sulfur is a significant component of many co-factor of enzymes (Table 3), having an indispensable effect on crops growth (Sarwar et al. 2010). Application of S fertilizer may decrease $\mathrm{Cd}$ toxicity by insoluble $\mathrm{CdS}$ formation (Table 3), by which reduces mobility of $\mathrm{Cd}$ in soil (Hassan et al. 2005). As well as effect of P fertilizer application, $\mathrm{S}$ also participates in GSH biosynthesis (Table 3), 
forming $\mathrm{Cd}-\mathrm{PC}$ complexes and reducing $\mathrm{Cd}$ toxicity by compartmentalization of Cd into vacuole (Cobbett 2000; Sarwar et al. 2010; Rizwan et al. 2016). However, Rehman et al. (2015) suggested that application of S fertilizer might enhance $\mathrm{Cd}$ concentration in rice grains by lowering soil $\mathrm{pH}$ and increase mobility of $\mathrm{Cd}$ (Table 3), which is negative effect of $\mathrm{S}$ fertilizer application. Therefore, Rizwan et al. (2016) proposed that combination of different mineral fertilizers contributed to decrease Cd uptake by rice compared with respective application. For instance, Wei et al. (2012) found that foliar application of combined Fe and $\mathrm{Zn}$ fertilizers might increase $\mathrm{Fe}$ and $\mathrm{Zn}$ content, decreasing $\mathrm{Cd}$ content in rice grains.

\section{Approaches for reducing grain $\mathrm{Cd}$ accumulation and enhancing Fe content}

Soil remediation methods are traditionally applied to reduce Cd toxicity to some extent, including soil removal, replacement, inversion and flooded condition before and after heading (Arao et al. 2009; Uraguchi and Fujiwara 2012). In addition, establishment of "low-Cd-rice" based on genetic findings is considered to be an effective approach to reduce $\mathrm{Cd}$ accumulation. There is genotypic variation in the $\mathrm{Cd}$ levels of grains in different rice cultivars. $\mathrm{Cd}$ accumulation in shoots and grains are greater in indica rice cultivars than in japonica cultivars (Ishikawa et al. 2005; Takahashi et al. 2011). Quantitative trait locus (QTL) analysis is a useful approach to identify responsible genes for the respective transport processes, such as various transporters (Ishikawa et al. 2010). QTL for Cd concentration in Anjana Dhan (indica rice cultivar) is identified on chromosome 7 , responsive gene for which is OsHMA3 (Ishikawa et al. 2010; Ueno et al. 2010; Takahashi et al. 2011). Amino acid at position 80 plays a key role in the function of OsHMA3 and mutation of this amino acid in Anjana Dhan makes Cd fail to be sequestered into vacuoles in root cells, accelerating translocation of $\mathrm{Cd}$ from roots to shoots (Ueno et al. 2010; Takahashi et al. 2011). Abe et al. (2011) introduced a non-functional allele of OsHMA3 from Jarian (indica rice cultivar) into Koshihikari (japonica rice cultivar) by marker-assisted selection and these plants showed reduced $\mathrm{Cd}$ uptake from soil. Regulation of genes for $\mathrm{Cd}$ transporters can also effectively reduce $\mathrm{Cd}$ accumulation in rice (Ueno et al. 2010). Suppression of OsLCT1 expression can decrease grain $\mathrm{Cd}$ accumulation by RNAi without influencing nutrient accumulation. On the contrary, $\mathrm{Fe}$ content in the brown rice is remarkably higher (Uraguchi et al. 2011), suggesting that RNAi-mediated OsLCT1 suppression in rice is a promising approach to establish "high Fe but low-Cd-rice". Furthermore, a novel rice gene low cadmium $(L C D)$ is related to Cd tolerance (Uraguchi and Fujiwara, 2012). This T-DNAmediated OsLCD knockout mutant showed reduced grain $\mathrm{Cd}$ accumulation by insertion into the first intron of $O s L C D$, having no negative effects on grain yield (Shimo et al. 2011). The authors indicated that the $l c d$ mutant might be a probable mutant line for further research.

Improving bioavailability of $\mathrm{Fe}$ is the main goal for breeding Fe-rich rice. A variety of approaches have been utilized to enhance Fe content in grains. Goto et al. (1999) demonstrated that high level of Fe in rice endosperm could be acquired by overexpression of ferritin. Combination of up-regulated expression of ferritin with overproduction of NA can significantly enhance Fe content (Wirth et al. 2009). Zheng et al. (2010) indicated that biofortifying rice with NA could efficiently enhance $\mathrm{Fe}$ bioavailability by over-expression OsNAS1 in rice endosperm, suggesting that NA plays a great potential role in enhancing Fe bioavailability. In addition, manipulation of specific transporters involved in Fe uptake and translocation is considered to be another promising approach for enhancing Fe content. Ishimaru et al. (2010) introduced OsYSL2 mediated by sucrose transporter (OsSUT1) promoter into rice plants due to location of OsSUT1 around endosperm, resulting in high concentration of Fe in polished rice.

In recent years, studies on rice screened for Fe-rich but Cd-free cultivars have been an important issue to agricultural field. Olive et al. (2014) bred an over-accumulated ferritin cultivars with rice mega-variety IR64 that serve as background. Compared with IR64 wild type, Fe content was increased in grains by introducing ferritin into endosperm. Such a ferritin-bioengineered diet is considered to be effective for mammal assimilation of $\mathrm{Fe}$ nutrition (Murray-Kolb et al. 2002; Olive et al. 2014). Moreover, Booyaves et al. (2016) expressed Arabibopsis IRT1( $A$ tIRT1) in high-iron NFP rice lines, which expressed NICOTIANAMINE SYNTHASE (AtNAS1) and FERRITIN, suggesting that coordinated expression of AtIRT1, AtNAS1 and PvFERRITIN enhanced Fe content in both unpolished and polished grains. Thus, combined expression of genes encoding Fe transporters or Fe storage proteins are promising approach for Fe biofortification. With regard to breeding low Cd cultivars, Ishikawa et al. (2012) identified and screened three low-Cd mutants (lcd-kmt1, $l c d-k m t 2$ and $l c d-k m t 3)$ with japonica rice cultivar, Koshihikari, which acted as parent by the way of carbon ionbeam irradiation, showing that there were lower $\mathrm{Cd}$ concentration in grains of the three mutants than Koshihikari wide type (WT). Such three low-Cd mutants were attributed to mutations of OSNRAMP5 responsible for $\mathrm{Cd}$ transport in rice by sequence analysis (Ishikawa et al. 2012). The three low-Cd mutants have different mutation sites in OsNRAMP5. An insertion of transposon mPingA1, which was activated by ion beam and preferred to insert into exon of OsNRAMP5 was identified in lcd-kmt1, 
resulting in non-function of OsNRAMP5 and decreased $\mathrm{Cd}$ accumulation in grains (Ishikawa et al. 2012). Similar results were observed in $l c d-k m t 2$ and $l c d-k m t 3$ due to a single-base pair deletion and a large deletion in $O s N$ RAMP5, respectively (Ishikawa et al. 2012). Meanwhile, Ishikawa et al. (2012) proposed that lcd-kmt1 and $l c d-k m t 2$ were more promising for breeding program according to agronomic traits, as a consequence of earlier heading and smaller plant size than Koshihikari WT in $l c d-k m t 3$ (Ishikawa et al. 2012). In addition, Abe et al. (2013) developed a novel population composed of 46 chromosome segment substitution lines (CSSLs), in which LAC23 served as donor segments and were substituted into background, Koshihikari. LAC23 could result in lower grain-to-straw ratio than Koshihikari (Abe et al. 2013). Therefore, Cultivars containing LAC23 performed low Cd content in grains (Abe et al. 2013). QTL mapping detected a major QTL, qlGCd3, and LAC23 allele at $q l G C d 3$ were identified to be related with reduced $\mathrm{Cd}$ content in grains (Abe et al. 2013). This result showed that low-Cd trait of LAC23 is promising for breeding low-Cd rice cultivars.

\section{Conclusions and perspectives}

Fe is essential nutrient for rice growth and humans consuming rice as their staple food, whereas $\mathrm{Cd}$ is nonessential and toxic. Rice grains contain both $\mathrm{Fe}$ and $\mathrm{Cd}$. The latter may cause damage to human bodies if accumulating at high levels. Basic transport processes are as follows: During the vegetative stage, $\mathrm{Fe}$ and $\mathrm{Cd}$ are absorbed by specific root transporters and then transport to xylem, delivering to aerial parts via xylem-tophloem transfer system. Compared with $\mathrm{Cd}$ of which such transfer system mainly operating at nodes, Fe is preferentially allocated to leaves through xylem. At grain-filling, grain $\mathrm{Fe}$ and $\mathrm{Cd}$ are derived from phloem. Particularly, grain Fe is largely acquired from leaves by remobilization. Due to limited source of $\mathrm{Fe}$ in soil and $\mathrm{Cd}$ toxicity, rice has evolved mechanisms against $\mathrm{Fe}$ deficiency and $\mathrm{Cd}$ stress. Rice can secrete DMA to chelate insoluble $\mathrm{Fe}^{3+}$ by strategy II. In response to $\mathrm{Cd}$ toxicity, compartmentalization of $\mathrm{Cd}$ into vacuole is thought to be effective tolerance mechanism for reducing $\mathrm{Cd}$ translocation to grains. However, relying on rice self-mechanisms are not enough to tackle issues of Fe deficiency and Cd toxicity. Besides traditional soil remediation and fertilizers management, breeding high $\mathrm{Fe}$ but low $\mathrm{Cd}$ cultivars through genetic methods are considered as promising approaches based on understanding of $\mathrm{Fe} / \mathrm{Cd}$ transport and accumulation processes at cellular level. QTL analysis, regulation and manipulation of genes involved in $\mathrm{Fe} / \mathrm{Cd}$ accumulation are generally utilized to produce novel cultivars.
Despite these advances in enhancing Fe in grains, limited Fe in edible parts due to combining with phytic acid and inevitable loss during polishing process restricts $\mathrm{Fe}$ nutritional assimilation for human bodies. In addition, some low-Cd cultivars are reported to enhance other toxic metals, such as Arsenic, though reduce Cd content to some extent. Thus, further investigation into these issues will be conducive to develop Fe-fortified cultivars with increased assimilation and low-Cd cultivars without other toxic metals accumulation.

\section{Acknowledgments}

This research was supported by Zhejiang provincial Nature Foundation (LY15C130007), Science Foundation of Zhejiang Sci-Tech University, Foundation of Zhejiang Provincial Top Key Discipline of Biology and Foundation of Zhejiang Provincial Key Discipline of Botany,the National Nature Foundation (NO: 31201150), Special Foundation for Scientific Research in National Research Institutes (NO: 2012RG004-3), National commonweal agricultural project (NO: 201203029), National Rice production system project (CARS-01-27),

\section{Authors' contributions}

LG wrote the manuscript with critical revision by JX, HFL and LXT. JDC participated in the data analysis. RJC and HBL participated in collecting the data of the related researches. All of the authors read and approved the final manuscript.

\section{Competing interests}

The authors declare that they have no competing interests.

\section{Author details}

'College of Life Sciences, Zhejiang Sci-Tech University, Hangzhou 310018, People's Republic of China. ${ }^{2}$ Zhejinag Province Key Laboratory of Plant Secondary Metabolism and Regulation, Hangzhou 310018, People's Republic of China. ${ }^{3}$ State Key Laboratory of Rice Biology, China National Rice Research Institute, Hangzhou 310006, People's Republic of China.

Received: 6 June 2016 Accepted: 31 July 2016

Published online: 08 August 2016

\section{References}

Abe T, Taguchi-Shiobara F, Kojima Y, Ebitani T, Kuramata M, Yamamoto T, Yano M, Ishikawa S (2011) Detection of a QTL for accumulating Cd in rice that enables efficient $\mathrm{Cd}$ phytoextraction from soil. Breeding Sci 61:43-51

Abe T, Nonoue Y, Ono N, Omoteno M, Kuramata M, Fukuoka S, Yamamoto T, Yano M, Ishikawa S (2013) Detection of QTLs to reduce cadmium content in rice grains using LAC23/ Koshihikari chromosome segment substitution lines. Breeding Sci 63:284-291

Araki R, Kousaka K, Namba K, Murata Y, Murata J (2015) 2'-Deoxymugineic acid promotes growth of rice (Oryza sativa) by orchestrating iron and nitrate uptake processes under high pH conditions. Plant J 81:233-246

Arao T, Kawasaki A, Baba K, Mori S, Matsumoto S (2009) Effects of water management on cadmium and arsenic accumulation and dimethylarsinic acid concentrations in Japanese rice. Environ Sci Tech 43:9361-9367

Aravind P, Prasad MN, Malec P, Waloszek A, Strzalka K (2009) Zinc protects Ceratophyllum demersum $\mathrm{L}$. (free-foating hydrophyte) against reactive oxygen species induced by cadmium. J Trace Elem Med Biol 23:50-60

Ariga T, Hazama K, Yanagisawa S, Yoneyama T (2014) Chemical forms of iron in xylem sap from graminaceous and non-graminaceous plants. Soil Sci Plant Nutr 60:460-469

Bolan N, Adriano DC, Duraisamy P, Mani A, Arulmozhiselvan K (2003) Immobilization and phytoavailability of cadmium in variable charge soils. I. Effect of phosphate addition. Plant Soil 250:83-94

Booyaves K, Gruissem W, Bhullar NK (2016) NOD promoter-controlled AtIRT1 expression functions synergistically with NAS and FERRITIN genes to increase iron in rice grains. Plant Mol Biol 90:207-215

Carrier P, Baryla A, Havaux M (2003) Cadmium distribution and microlocalization in oilseed rape (Brassica napus) after long-term growth on cadmiumcontaminated soil. Planta 216:939-950 
Cheng LJ, Wang F, Shou HX, Huang FL, Zheng LQ, He F, Li JH, Zhao FJ, Uneo D Ma JF, Wu P (2007) Mutation in nicotianamine aminotransferase stimulated the Fe(II) acquisition system and led to iron accumulation in rice. Plant Physiol 145:1647-1657

Choppala G, Saifullah Bolan N, Bibi S, lqbal M, Rengel Z, Kunhikrishinan A, Ashwath N, Ok YS (2014) Cellular mechanisms in higher plants governing tolerance to cadmium toxicity. Crit Rev Plant Sci 33:374-391

Cobbett CS (2000) Phytochelatins and their roles in heavy metal detoxicification. Plant Physiol 23:825-832

Conte SS, Walker EL (2011) Transporters contributing to iron trafficking in plants. Mol Plant 4:464-476

Cordell D, Drangert JO, White S (2009) The story of phosphorus: Global food security and food for thought. Global Environ Change 19:292-305

Crawford NM (2006) Mechanisms for nitric oxide synthesis in plants. J. Exp Bot $57: 471-478$

Curie C, Panaviene Z, Loulergue C, Dellaporta SL, Brait JF, Walker EL (2001) Maize yellow stripe 1 encodes a membrane protein directly involved in $\mathrm{Fe}(\mathrm{III})$ uptake. Nature 409:346-349

Curie C, Cassin G, Couch D, Divol F, Higuchi K, Le Jean M, Misson J, Schikora A, Czernic P, Mari S (2009) Metal movement within the plant: contribution of nicotianmine and yellow stripe1-like transporters. Ann Bot 103:1-11

DalCorso G, Farinati S, Furini A (2010) Regulatory networks of cadmium stress in plants. Plant Signal Behav 5:663-667

Dong J, Mao WH, Zhang GP, Wu FB, Cai Y (2007) Root excretion and plant tolerance to cadmium toxicity-a review. Plant Soil Environ 53:193

Enstone DE, Peterson CA, Ma F (2002) Root endodermis and exodermis: structure, function, and responses to the environment. J Plant Growth Regul 21:335-351

Eriksson JE (1990) Effects of nitrogen-containing fertilizers on solubility and plant uptake of cadmium. Water Air Soil Pollut 49:355-368

Fahad S, Hussain S, Khan F, Wu C, Saud S, Hassan S, Ahmad N, Gang D, Ullah A, Huang J (2015) Effects of tire rubber ash and zinc sulfate on crop productivity and cadmium accumulation in five rice cultivars under field conditions. Environ Sci Pollut Res Int 22:12424-12434

Fujimaki S, Suzui N, Ishioka NS, Kawachi N, Ito S, Chino M, Nakamura S (2010) Tracing cadmium from culture to spikelet: Noninvasive imaging and quantative characterization of absorption, transport, and accumulation of cadmium in an intact rice plant. Plant Physiol 152:1796-1806

Goto F, Yoshihara T, Shigemoto N, Toki S, Takaiwa F (1999) Iron fortification of rice seed by the soybean ferritin gene. Nat Biotechnol 17:282-286

Hassan MJ, Wang F, Ali S, Zhang G (2005) Toxic effect of cadmium on rice as affected by nitrogen fertilizer form. Plant Soil 277:359-365

Horiguchi H, Aoshima K, Oguma E, Sasaki S, Miyamoto K, Hosoi Y, Katoh T, Kayama F (2010) Latest status of cadmium accumulation and its effects on kidneys, bone, and erythropoiesis in inhabitants of the formly cadmiumpolluted Jinzu River Basin in Toyama, Japan, after restoration of rice paddies. Int Arch Occ Environ Hea 83:953-970

Inoue H, Higuchi K, Takahashi M, Nakanishi H, Mori S, Nishizawa NK (2003) Three rice nicotianamine synthase genes, OsNAS1, OsNAS2, and OsNAS3 are expressed in cells invovled in long-distance transport of iron and differentially regulated by iron. Plant J 36:366-381

Inoue H, Takahashi M, Kobayashi T, Suzuki M, Nakanishi H, Mori S, Nishizawa NK (2008) Identification and localisation of the rice nicotianamine aminotransferase gene OSNAAT1 expression suggests the site of phytosiderophore synthesis in rice. Plant Mol Biol 66:193-203

Inoue H, Kobayashi T, Nozoye T, Takahashi M, Kakei Y, Suzuki K, Nakazono M, Nakanishi H, Mori S, Nishizawa NK (2009) Rice OsYSL15 is an iron-regulated iron(III)-deoxymugineic acid transporter expressed in the roots and is essential for iron uptake in early growth of the seedlings. J Biol Chem 284:3470-3479

Ishikawa S, Ae N, Sugiyama M, Murakami M, Arao T (2005) Genotypic variation in shoot cadmium concentration in rice and soybean in soils with different levels of cadmium contamination. Soil Sci Plant Nutr 51:101-108

Ishikawa S, Abe T, Kuramata M, Yamaguchi M, Ando T, Yamamoto T, Yano M (2010) A major quantitative trait locus for increasing cadmium-specific concentration in rice grain is located on the short arm of chromosome 7. J Exp Bot 61:923-934

Ishikawa S, Suzui N, Ito-Tanabata S, Ishii S, Igura M, Abe T, Kuramata M, Kawachi N, Fujimaki S (2011) Real-time imaging and analysis of differences in cadmium dynamics in rice cultivars (Oryza sativa) using positron-emitting ${ }^{107} \mathrm{Cd}$ tracer. BMC Plant Biol 11:172
Ishikawa S, Ishimaru Y, Igura M, Kuramata M, Abe T, Senoura T, Hase Y, Arao T, Nishizawa NK, Nakanishi H (2012) lon-beam irradiation, gene identification, and marker-assisted breeding in the development of low-cadmium rice. Proc Natl Acad Sci U S A 109:19166-19171

Ishimaru Y, Masuda H, Bashir K, Inoue H, Tsukamoto T, Takahashi M, Nakanishi H, Aoki N, Hirose T, Ohsugi R, Nishizawa NK (2010) Rice metal-nicotianamine transporter, OsYSL2, is required for the long-distance transport of iron and manganese. Plant J 62:379-390

Ishimaru Y, Kakei Y, Shimo H, Bashir K, Sato Y, Uozumi N, Nakanishi H, Nishizawa NK (2011) A rice phenolic efflux transporter is essential for solubilizing precipitated apoplasmic iron in the plant stele. J Biol Chem 286:24649-24655

Ishimaru Y, Takahashi R, Bashir K, Shimo H, Senoura T, Sugimoto K, OnoK YM, Ishikaw S, Arao T, Nakanishi H, Nishizawa NK (2012) Characterizing the role of rice NRAMP5 in manganese, iron and cadmium transport. Sci Rep 2:286

Jalloh MA, Chen J, Zhen F, Zhang G (2009) Effect of different N fertilizer forms on antioxidant capacity and grain yield of rice growing under $\mathrm{Cd}$ stress. J Hazard Mater 162:1081-1085

Johanning J, Strasdeit H (1998) A Coordination-Chemical Basis for the Biological Function of the Phytochelatins. Angew Chem Int Ed 37:2464-2465

Kakei Y, Ishimaru Y, Kobayashi T, Yamakawa T, Nakanishi H, Nishizawa NK (2012) OsYSL16 plays a role in the allocation of iron. Plant Mol Biol 79:583-594

Khaokaew S, Chaney RL, Landrot G, Ginder-Vogel M, Sparks DL (2011) Speciation and release kinetics of cadmium in an alkline paddy soil under various flooding periods and draining conditions. Environ Sci Technol 45:4249-4255

Kobayashi T, Nishizawa NK (2012) Iron uptake, translocation and regulation in higher plants. Annu Rev Plant Biol 63:131-152

Kobayashi T, Nakanishi H, Nishizawa NK (2010) Recent insights into iron homestasis and their application in graminaceous crops. Proc Jpn Acad Ser B Phys Biol Sci 86:900-913

Kobayashi T, Itai RN, Nishizawa NK (2014) Iron deficiency responses in rice roots. Rice 7:27

Koike S, Inoue H, Mizuno D, Takahashi M, Nakanishi H, Mori S, Nishizawa NK (2004) OsYSL2 is a rice metal-nicotianamine transporter that is regulated by iron and expressed in the phloem. Plant J 39:415-424

Lambert R, Grant C, Sauvé S (2007) Cadmium and zinc in soil solution extracts following the application of phosphate fertilizers. Sci Total Environ 378:293305

Lang L, Wernitznig S (2011) Sequestration at the cell wall and plasma membrane facilitates zinc tolerance in the moss Pohlia drummondii. Envion Exp Bot 74:186-193

Liu X, Jin W, Theil EC (2003) Opening protein pores with chaotropes enhances Fe reduction and chelation of Fe from the ferritin biomineral. Proc Natl Acad Sci U S A 100:3653-3658

Liu H, Zhang J, Christie P, Zhang F (2008) Influence of iron plague on uptake and accumulation of $\mathrm{Cd}$ by rice (Oryza sativa L.) seedlings grown in soil. Sci Total Environ 394:361-368

May MJ, Vernoux T, Leaver C, Van Montagu M, Inzé D (1998) Glutathione homeostasis in plants: implications for environmental sensing and plant development. J Exp Bot 49:649-667

Mitchell L, Grant CA, Racz GJ (2000) Effect of nitrogen application of concentration of cadmium and nutrient ions in soil solution and in durum wheat. Can J Soil Sci 80:107-115

Miyadate H, Adachi S, Hiraizumi A, Tezuka K, Nakazawa N, Kawamoto T, Katou K, Kodama I, Sakurai K, Takahashi H, Satoh-Nagasawa N, Watanabe A, Fujimura

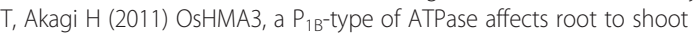
cadmium translocation in rice by mediating efflux into vacuoles. New Phytol 189:190-199

Mori S (1999) Iron acquisition by plants. Curr Opin Plant Biol 2:250-253

Murray-Kolb LE, Takaiwa F, Goto F, Yoshihara T, Theil EC, Beard JL (2002) Transgenic rice is a source of iron for iron-depleted rats. J Nutr 132:957-960

Nakanishi H, Ogawa I, Ishimaru Y, Mori S, Nishizawa NK (2006) Iron deficiency enhances cadmium uptake and translocation mediated by the $\mathrm{Fe}^{2+}$ transporters OsIRT1 and OSIRT2 in rice. Soil Sci Plant Nutr 52:464-469

Nocito FF, Lancilli C, Dendena B, Lucchini G, Sacchi GA (2011) Cadmium retention in rice roots is influenced by cadmium availability, chelation and translocation. Plant Cell Environ 34:994-1008

Nozoye T, Nagasaka S, Kobayashi T, Takahashi M, Sato Y, Uozumi N, Nakanishi H, Nishizawa NK (2011) Phytosiderophore efflux transporters are crucial for iron acquisition in graminaceous plants. J Biol Chem 286:5446-5454 
Oda K, Otani M, Uraguchi S, Akihiro T, Fujiwara T (2011) Rice ABCG43 is a Cd inducible and confers $\mathrm{Cd}$ tolerance on yeast. Biosci Biotech Biochem 75:1211-1213

Ogo Y, Kakei Y, Itai RN, Kobayashi T, Nakanishi H, Takahashi H, Nakazono M, Nishizawa NK (2014) Spatial transcriptomes of iron-deficient and cadmiumstressed rice. New Phytol 201:781-794

Olive N, Chadha-Mohanty P, Poletti S, Abrigo E, Atienza G, Torrizo L, Garcia R, Dueñas C Jr, Poncio MA, Balindong J, Manzanilla M, Montecillo F, Zaidem M, Barry G, Hervé P, Shou H, Slamet-Loedin IH (2014) Large-scale production and evaluation of marker-free indica rice IR64 expressing phytoferritin genes. Mol Breed 33:23-37

Pich A, Manteuffel R, Hillmer S, Scholz G, Schmidt W (2001) Fe homeostasis in plant cells: does nicotianamine play multiple roles in the regulation of cytoplasmic Fe concentration? Planta 213:967-976

Rauser WE (1995) Phytochelatins and related peptides. structure, biosynthesis, and function. Plant Physiol 109:1141-1149

Ravet K, Touraine B, Boucherez J, Briat JF, Gaymard F, Cellier F (2009) Ferritins control interaction between iron homeostasis and oxidate stress in Arabidopsis. Plant J 57:400-412

Rehman MZ, Rizwan M, Ghafoor A, Naeem A, Ali S, Sabir M, Qayyum MF (2015) Effect of iorganic amendments for in situ stabilization of cadmium in contaminated soils and its phyto-availability to wheat and rice under rotation. Environ Sci Pollut Res Int 22:16897-16906

Rizwan M, Ali S, Abbas T, Zia-Ur-Rehman M, Hannan F, Keller C, Al-Wabel MI, Ok YS (2016) Cadmium minimization in wheat: A critical review. Ecotoxicol Environ Saf 130:43-53

Sarwar N, Saifullah MSS, Zia MH, Naeem A, Bibi S, Farid G (2010) Role of mineral nutrition in minimizing cadmium accumulation by plants. J Sci Food Agric 90:925-937

Sasaki A, Yamaji N, Yokosho K, Ma JF (2012) Nramp5 is a major transporter responsible for manganese and cadmium uptake in rice. Plant Cell 24:2155-2167

Schwab AP, He Y, Banks MK (2005) The influence of organic ligands on the retention of lead in soil. Chemosphere 61:856-866

Shahid M, Dumat C, Khalid S, Niazi NK, Antunes PMC (2016) Cadmium bioavailability, uptake, toxicity and detoxification in soil-plant system. doi:10.1007/398_2016_8

Shao G, Chen M, Wang D, Xu C, Mou R, Cao Z, Zhang X (2008) Using iron fertilizer to control $\mathrm{Cd}$ accumulation in rice plants: a new promising technology. Sci China C Life Sci 51:245-253

Sharma SS, Kaul S, Metwally A, Goyal KC, Finkemeier I, Dietz KJ (2004) Cadmium toxicity to barley (Hordeum vulgare) as affected by varying Fe nutritional status. Plant Sci 166:1287-1295

Shimo H, Ishimaru Y, An G, Yamakawa T, Nakanishi H, Nishizawa NK (2011) Low cadmium (LCD), a novel gene related to cadmium tolerance and accumulation in rice. J Exp Bot 62:5727-5734

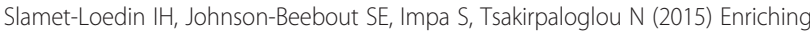
rice with $\mathrm{Zn}$ and Fe while minimizing $\mathrm{Cd}$ risk. Front in Plant Sci 6:121

Smilde KW, Van Luit B, Van Driel W (1992) The extraction by soil and absorption by plants of applied zinc and cadmium. Plant Soil 143:233-238

Takahashi M, Terda Y, Nakai I, Nakanishi H, Yoshimura E, Mori S, Nishikawa NK (2003) Role of nicotianamine in the itracellular delivery of metals and plant reproductive devolopment. Plant Cell 15:1263-1280

Takahashi R, Ishimaru Y, Senoura T, Shimo H, Ishikawa S, Arao T, Nakanishi H, Nishizawa NK (2011) The OsNRAMP1 iron transporter is involved in Cd accumulation in rice. J Exp Bot 62:4843-4850

Takahashi R, Bashir K, Ishimaru Y, Nishikawa NK, Nakanishi H (2012a) The role of heavy-metal ATPases, HMAs, in Zinc and Cadmium transport in rice. Plant Signal Behav 7:1605-1607

Takahashi R, Ishimaru Y, Shimo H, Ogo Y, Senoura T, Nishizawa NK, Nakanishi H (2012b) The OsHMA2 transporter is involved in root-to-shoot translocation of Zn and Cd in rice. Plant Cell Environ 35:1948-1957

Ueno D, Yamaji N, Kono I, Huang CF, Ando T, Yano M, Ma JF (2010) Gene limiting cadmium accumulation in rice. Proc Natl Acad Sci U S A 107:16500-16505

Uraguchi S, Fujiwara T (2012) Cadmium transport and tolerance in rice: perspectives for reducing grain cadmium accumulation. Rice 5:5

Uraguchi S, Kamiya T, Sakamoto T, Kasaki K, Sato Y, Nagamura Y, Yoshida A Kyozuka J, Ishikawa S, Fujiwara T (2011) Low-affinity cation transporter (OsLCT1) regulates cadmium transport into rice grains. Proc Natl Acad Sci U S A 108:20959-20964
Wang H, Wang PF, Zhang H (2009) Use of phosphorus to alleviate stress induced by cadmium and zinc in two submerged macrophytes. Afr J Biotechnol 8:2176-2183

Wang S, Wang F, Gao S (2015) Foliar application with nano-silicon alleviates Cd toxicity in rice seedlings. Environ Sci Pollut Res Int 22:2837-2845

Wangstrand $\mathrm{H}$, Eriksso J, Oborn I (2007) Cadmium concentration in winter wheat affected by nitrogen fertilization. Eur J Agron 26:209-214

Weber G, von Wrien N, Hayen H (2008) Investigation of ascoebate-mediated iron release from ferric phytosiderophores in the presence of nicotianamine. Biometals 21:503-513

Wei Y, Shohag MJ, Yang X, Yibin Z (2012) Effects of foliar iron application on iron concentration in polished rice grain and its bioavailability. J Agric Food Chem 60:11433-11439

White PJ, Broadley MR (2011) Physiological limits to zinc biofortification of edible crops. Front Plant Sci 2:80

William LE, Mills RF (2005) P1 $1_{B}$-ATPases-an ancient family of transition metal pumps with diverse functions in plants. Trends Plant Sci 10:491-502

Wirth J, Poletti S, Aeschlimann B, Yakandawala N, Drosse B, Osorio S, Tohge T, Fernie AR, Günther D, Gruissem W, Sautter C (2009) Rice endosperm iron biofortification by targeted and synergistic action of nicotianamine synthase and ferritin. Plant Biotechnol J 7:631-644

Xie HL, Jiang RF, Zhang FS, McGrath SP, Zhao FJ (2009) Effect of nitrogen form on the rhizosphere dynamics and uptake of cadmium and zinc by the hyperaccumulator Thlaspi caerulescens. Plant Soil 318:205-215

Xiong J, An L, Lu H, Zhu C (2009) Exogenous nitric oxide enhances cadmium tolerance of rice by increasing pectin and hemicellulose contents in root cell wall. Planta 230:755-765

Xue Q, Harrison HC (1991) Effect of soil zinc, pH and cultivar uptake in leaf lettuce. (Lactuca sativa L. var. crispa). Common soil Sci Plant Anal 22:975-991

Yadav R, Arora P, Kumar S, Chaudhury A (2010) Perspectives for genetic engineering of poplars for enhanced phytoremediation abilities. Ecotoxicology 19:1574-1588

Yamagi N, Xia J, Mitani-Ueno N, Yokosho K, Feng Ma J (2013) Preferential delivery of zinc to developing tissues in rice is mediated by P-type heavy metal ATPase OsHMA2. Plant Physiol 162:927-39

Yamaguchi N, Ishikawa S, Abe T, Baba K, Arao T, Terada Y (2012) Role of the node in controlling traffic of cadmium, zinc, and manganese in rice. J Exp Bot 63:2729-2737

Yang Y, Chen R, Fu G, Xiong J, Tao L (2016a) Phosphate deprivation decreases cadmium (Cd) uptake but enhances sensitivity to $\mathrm{Cd}$ by increasing iron (Fe) uptake and inhibiting phytochelatins synthesis in rice (Oryza sativa). Acta Physiol Plant 38:1-13

Yang Y, Xiong J, Chen R, Fu G, Chen T, Tao L (2016b) Excessive nitrate enhances cadmium (Cd) uptake by up-regulating the expression of OsIRT1 in rice (Oryza sativa). Environ Exp Bot 122:141-149

Yokosho K, Yamaji N, Ueno D, Mitani N, Ma JF (2009) OsFRDL1 is a citrate transporter required for efficient transformation of iron in rice. Plant Physiol 149:297-305

Yoneyama T, Ishikawa S, Fujimaki S (2015) Route and regulation of zinc, cadmium, and iron transport in rice plants (Oryza sativa L.) during vegetative growth and grain filling: metal transporters, metal speciation, grain $\mathrm{Cd}$ reduction and $\mathrm{Zn}$ and Fe biofortification. Int J Mol Sci 16:19111-19129

Zaccheo P, Crippa L, Pasta VDM (2006) Ammonium nutrition as a strategy for cadmium mobilisation in the rhizosphere of sunflower. Plant Soil 283:43-56

Zhang Y, Xu YH, Yi HY, Gong JM (2012) Vacuolar membrane transporters OsVIT1 and OsVIT2 modulate iron translocation between flag leaves and seeds in rice. Plant J 72:400-410

Zheng $L$, Cheng Z, Ai C, Jiang X, Bei X, Zheng Y, Glahn RP, Welch RM, Miller DD, Lei $X G$, Shou $H$ (2010) Nicotianamine, a novel enhancer of rice iron bioavailability to humans. PLoS One 5:e10190 